\title{
Depressive symptoms post hip fracture in older adults are associated with phenotypic and functional alterations in T cells
}

\author{
Niharika Arora Duggal ${ }^{1,2}$, Jane Upton ${ }^{3}$, Anna C Phillips ${ }^{2,3}$, Peter Hampson ${ }^{1,2}$ and Janet M Lord ${ }^{1,2^{*}}$
}

\begin{abstract}
Background: Ageing is accompanied by reduced immunity, termed immunesenescence. The immune system does not act in isolation and is sensitive to both psychological and physical stress. Hip fracture is a common physical stressor in older adults with a high incidence of new onset depression, which relates to poorer prognosis. We therefore set out to examine the possible synergistic effects of physical stress (hip fracture) and psychological stress (depressive symptoms) on the aged immune system.

Results: T cell phenotype and function was assessed in 101 hip fracture patients (81 female) 6 weeks after hip fracture and 43 healthy age-matched controls ( 26 female). 38 fracture patients had depressive symptoms at 6 weeks. T cell frequency $(p=.01)$ and numbers $(p=.003)$ were both lower in depressed hip fracture patients compared to healthy controls. The frequency of senescent CD28 ${ }^{-v e}(p=.001), C D_{5} 7^{+v e}(p=.001), K_{L R G} 1^{\text {tve }}(p=.03)$ CD8 T cells, as well as senescent $C D 28^{-v e} C D^{+v e}(p=.01)$ and $C D 57^{+v e} C D^{+v e}(p=.003) T$ cells were higher in depressed hip fracture patients compared with healthy controls and the frequency of CD28-ve CD8 T cells was also higher when compared to patients with hip fracture alone $(p=.01)$. Additionally, activated $\operatorname{CD}^{\circ} 9^{\text {+ve }}(p=.005)$ and HLADR $R^{+v e}$ $(p<.001)$ CD8 T cells, were also higher in depressed hip fracture patients compared to healthy controls. On examining cytokine production by activated T cells, a significant increase in TNFa $(p=.03)$ and IL6 $(p=.04)$ production was observed in CD4 T cells from hip fracture patients with depressive symptoms compared to healthy controls.

Conclusions: As none of the patients in the study had a prior history of depression, our data suggest that the development of depressive symptoms in hip fracture patients is associated with altered T cell phenotype and increased pro-inflammatory function which is not seen in patients who do not develop depression after hip fracture. Treating depressive symptoms promptly in hip fracture patients may therefore improve immunity and outcomes in these patients.
\end{abstract}

Keywords: Depressive symptoms, Hip fracture, T cell, Stress, Immunity, Inflammation, Ageing, Cortisol

\section{Background}

Healthy ageing is associated with a significant decline in immune competence and ability to mount a robust immune response, termed immunesenescence [1]. This compromised immune response is due in large part to extensive remodelling of the adaptive immune system including thymic atrophy [2], a decrease in the CD4:

\footnotetext{
* Correspondence: J.M.Lord@bham.ac.uk

'School of Immunity and Infection, University of Birmingham, Birmingham B15 2TT, UK

${ }^{2}$ MRC-Arthritis Research UK Centre for Musculoskeletal Ageing Research and, University of Birmingham, Birmingham B15 2TT, UK

Full list of author information is available at the end of the article
}

CD8 ratio [3,4] and an increase in the naïve: memory $\mathrm{T}$ cell ratio $[4,5]$. Immune ageing also includes marked phenotypic alterations in $\mathrm{T}$ cells associated with functional senescence, notably loss of the co-stimulatory receptor CD28 and acquisition of receptors normally associated with Natural Killer cells, for example KLRG-1 [6]. The result is an accumulation with age of $\mathrm{CD} 28^{-\mathrm{ve}}$, KLRG- $1^{+v e}$, CD57 $7^{\text {ve }}$ senescent $\mathrm{T}$ cells $[7,8]$ as well as activated HLADR ${ }^{+v e}$ T cells [9]. Furthermore, ageing is accompanied by a decline in CD4 helper activity [10] and a shift from a Th1 (IFNY, IL2) to Th2 (IL10, IL4) phenotype on activation [11], but an increase in pro-inflammatory cytokine production by $\mathrm{T}$ cells overall $[12,13]$. 
Healthy older individuals have been reported to experience greater levels of stress, anxiousness and depression than young adults [14]. Meta-analysis of the literature over the past few decades has led to the development of the hypothesis that chronic stressful events are suppressors of immune function [15]. Interestingly, there is accumulating evidence suggesting that the effects of stress and age are interactive with chronic stress exacerbating the effects of ageing on immune function [16]. Our own work has shown that innate immunity is susceptible to the effects of stress, with neutrophil superoxide generation reduced in old hip fracture patients [17] and bereaved older adults [18].

Hip fracture is a common and potentially devastating injury in older adults [19]. 1 in 3 older adults fall each year and it is predicted that this will result in 117,000 hip fractures by 2016 [20]. Even though hip fracture is treatable, it is a severe physical stressor for older individuals. Medical events in older adults have been associated with a significant risk of developing depression [21] and a high rate of depression, ranging from 9 - 47\%, has been reported in UK and US based studies of older adults with hip fracture [22]. Importantly, depression is associated with increased risk of infections and poor survival [23], impaired recovery and a reduced ability to regain pre-fracture levels of physical functioning [24].

The hypothalamus-pituitary-adrenal (HPA) axis acts as a pivotal regulator of the stress responses by mobilising energy reserves and modulating immune responses [25]. Glucocorticoids (GCs) are key effectors of the HPA axis and are potent immune suppressors. Dehydroepiandrosterone sulphate (DHEAS), a major steroid produced by the adrenal gland, has been reported to have antidepressive, anti-glucocorticoid and immune-enhancing properties [26]. Some previous studies have suggested that healthy ageing is accompanied by hyperactivation of the HPA axis, especially in situations of chronic stress, resulting in prolonged exposure to cortisol [27]. This is due also in large part to dramatic changes in the serum level of DHEAS which reaches peak concentrations during the third decade of life, after which a steady decline occurs with age (1-2\% per year); such that by the age of 80, DHEAS levels have reached $10-20 \%$ of their peak level [28]. Therefore, the current literature suggests that ageing is accompanied by an elevated cortisol:DHEAS ratio which may be a key factor contributing towards age associated immune dysregulation [29] and which might be heightened by chronic stress. In a previous study, our group reported a raised cortisol: DHEAS ratio in old hip fracture patients compared to comparable young trauma patients [30]. We have also reported recently that suppression of innate immunity, specifically neutrophil function, only occurred in those hip fracture patients that developed depressive symptoms [31].
The present study sought to test the hypothesis that psychological distress, specifically depressive symptoms, would act additively with the physical stress of hip fracture to amplify the effect of ageing upon adaptive immunity, with specific reference to $\mathrm{T}$ cells. It also examined the role of the cortisol and pro- and anti-inflammatory cytokines as potential mediators of any effects observed.

\section{Results}

\section{Participant demographics}

The full demographic profiles of the participants have been reported previously [31]. Patients were classified into two groups on the basis of their GDS scores: hip fracture patients with a GDS score of 5 or less were classified as non-depressed (HF; hip fracture only), those with a score of 6 or greater were categorised as having depressive symptoms (HF $+\mathrm{D}$; Hip fracture patients with depressive symptoms). In this study we observed that 38 (37\%) of the hip fracture patients had depressive symptoms 4-6 weeks after their fracture.

\section{Peripheral T cell numbers in hip fracture patients}

Peripheral T cells counts in hip fracture patients with and without depressive symptoms were compared with healthy older adults. Significant differences in percentages of $\mathrm{CD}^{+ \text {ve }} \mathrm{T}$ cells in the PBMC pool were found between the three groups, $F(2,101)=4.59, \mathrm{p}=.01, \eta^{2}=.08$, [Figure 1a], which was driven by a significant decline in percentage of $\mathrm{T}$ cells in hip fracture patients with depressive symptoms compared with healthy controls $(\mathrm{p}=.01)$ but not with hip fracture patients without depressive symptoms $(\mathrm{p}=.12)$. Similarly, on examining the absolute numbers of $\mathrm{T}$ cells in peripheral blood, significant differences were seen between our three groups, $\mathrm{F}(2,51)=7.18, \mathrm{p}=.002, \eta^{2}=.22$ [Figure 1b], with a decline shown in T cells in hip fracture patients with depressive symptoms compared with healthy controls $(\mathrm{p}=.003)$. When the above analyses were repeated with adjustment for age, sex and BMI, the results remained significant (data not shown).

\section{CD4:CD8 T cell ratio in hip fracture patients}

On examining the percentage of CD4 T cells, no significant differences were observed between our three groups, $\mathrm{F}(2,85)=.68, \mathrm{p}=.50, \eta^{2}=.01$ [Table 1]. However, significant differences occurred in absolute numbers of CD4 T cells, F $(2,52)=6.01, \mathrm{p}=.004, \eta^{2}=.18$, driven by a significant decline in absolute numbers of $\mathrm{CD} 4 \mathrm{~T}$ cells in hip fracture patients with depressive symptoms compared with healthy controls $(\mathrm{p}=.006)$ only. No significant differences were observed between the percentage of CD8 T cells, $\mathrm{F}(2,97)=.13, \mathrm{p}=.87$, $\eta^{2}=.003$, or in absolute numbers of CD8 T cells between our three groups, $\mathrm{F}(2,52)=1.31, \mathrm{p}=.27, \eta^{2}=.04$, [Table 1]. Thus no significant differences were seen in 


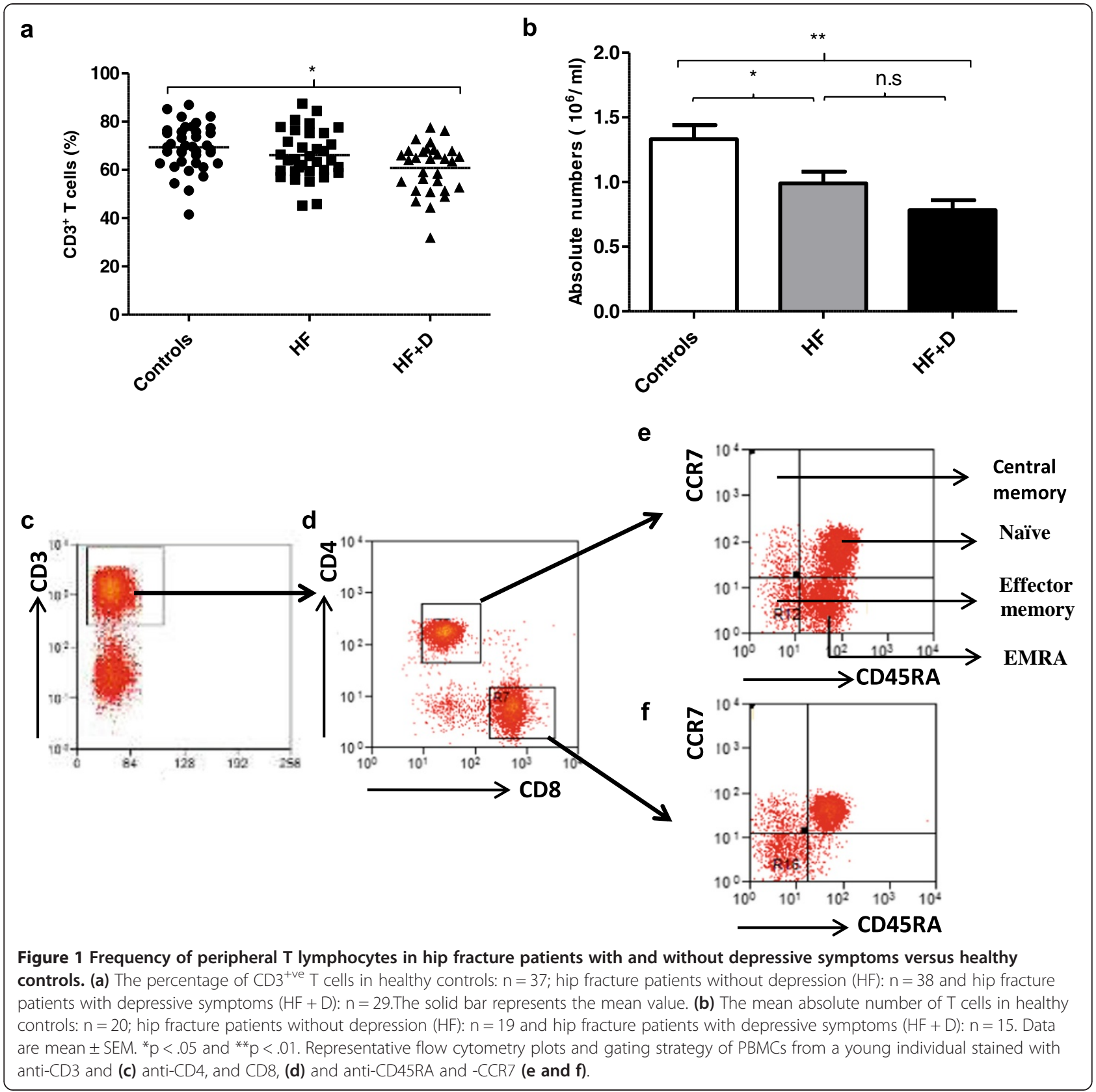

Table 1 Participant peripheral distribution of $\mathrm{T}$ cells by group

\begin{tabular}{|c|c|c|c|c|}
\hline \multirow[t]{2}{*}{ Variable } & \multirow[t]{2}{*}{ Controls } & \multicolumn{3}{|l|}{ Mean (SD) } \\
\hline & & HF & $H F+D$ & $p$ \\
\hline$\overline{\mathrm{CD}} 4^{+\mathrm{ve}} \mathrm{T}$ cells (\%) & $65.55(10.57)$ & $68.97(12.21)$ & $67.40(13.76)$ & .50 \\
\hline Absolute numbers $\left(10^{6} / \mathrm{ml}\right)$ & $.85(.26)$ & $.63(.29)$ & $.55(.22)$ & .004 \\
\hline $\mathrm{CD}^{+\mathrm{ve}} \mathrm{T}$ cells (\%) & $28.31(10.01)$ & $26.78(12.23)$ & $27.32(14.34)$ & .87 \\
\hline Absolute numbers $\left(10^{6} / \mathrm{ml}\right)$ & $.32(.22)$ & $.25(.16)$ & $.21(.18)$ & .27 \\
\hline CD4:CD8 ratio & $2.80(1.76)$ & $3.41(2.98)$ & $3.56(2.61)$ & .33 \\
\hline
\end{tabular}


the $\mathrm{CD} 4: \mathrm{CD} 8$ ratio between the three groups, $\mathrm{F}(2,97)=$ 1.11, $\mathrm{p}=.33, \eta^{2}=.02$ [Table 1].

\section{Memory: naive T cell ratio in hip fracture patients}

CD4 T cells and CD8 T cells can be divided into four differentiation subsets on the basis of expression of CD45RA and CCR7: naïve, central memory (CM), effector memory (EM) and terminally differentiated effector memory cells (EMRA) [32]. Figures 1c-f show representative FACs plots for PBMCs stained with anti-CD3 and anti-CD4, CD8, CD45RA and CCR7 antibodies to identify these subsets. On examining the percentage, $\mathrm{F}(2,85)=.13, \mathrm{p}=.87$, $\eta^{2}=.003$, and absolute numbers of naïve CD4 T cells in peripheral blood, $\mathrm{F}(2,51)=2.07, \mathrm{p}=.13, \eta^{2}=.07$ no significant differences were found between subject groups [Table 2]. Further, on examining central memory CD4 T cell subsets, no significant differences occurred in their percentages, $\mathrm{F}(2,86)=.90, \mathrm{p}=.40, \eta^{2}=.02$, or absolute numbers $\mathrm{F}(2,51)=1.37, \mathrm{p}=.26, \eta^{2}=.05$, between the three groups [Table 2]. Similarly, no significant differences were found in the percentage, $\mathrm{F}(2,86)=.20, \mathrm{p}=.81$, $\eta^{2}=.005$, or absolute numbers, $\mathrm{F}(2,51)=.77, \mathrm{p}=.46$, $\eta^{2}=.03$, of effector memory CD 4 T cells [Table 2]. Finally, no significant differences were seen in the percentage, $\mathrm{F}(2,86)=.23, \mathrm{p}=.79, \eta^{2}=.005$, or in absolute numbers of effector memory RA CD4 T cells, $\mathrm{F}(2,51)=1.83, \mathrm{p}=.16$, $\eta^{2}=.06$ [Table 2]. Thus, the naïve:memory ratio for CD4 T cells also did not significantly differ between hip fracture patients with and without depressive symptoms and healthy controls, $\mathrm{F}(2,89)=.21, \mathrm{p}=.80, \eta^{2}=.005$ [Table 2].

We then examined the distribution of naïve and memory cells amongst CD8 T cells. Firstly, no differences were observed in the percentage, $\mathrm{F}(2,85)=.05, \mathrm{p}=.94$, $\eta^{2}=.001$, or absolute numbers of naïve CD8 T cells $\mathrm{F}(2,51)=1.77, \mathrm{p}=.18, \eta^{2}=.06$, between the three groups [Table 3]. Further, on examining memory CD8 $\mathrm{T}$ cell subsets, no significant differences were observed in the percentage, $\mathrm{F}(2,85)=1.34, \mathrm{p}=.26, \eta^{2}=.03$, or absolute numbers $\mathrm{F}(2,51)=.80, \mathrm{p}=.45, \eta^{2}=.03$, of central memory CD8 $\mathrm{T}$ cells between the three groups [Table 3 ]. Similarly, no significant differences were found in the percentage, $\mathrm{F}(2,85)=2.77, \mathrm{p}=.07, \eta^{2}=.06$, or absolute numbers of effector memory CD8 T cells, $F(2,51)=1.21$, $\mathrm{p}=.30, \eta^{2}=.04$ [Table 3] and the percentage, $\mathrm{F}(2,85)=.55$, $\mathrm{p}=.57, \eta^{2}=.01$, and absolute numbers of effector memory RA CD8 T cells, $F(2,51)=.50, \mathrm{p}=.60, \eta^{2}=.01$, did not differ between groups [Table 3 ]. Thus, the naïve: memory ratio for CD8 $\mathrm{T}$ cells did not significantly differ between the three groups, $\mathrm{F}(2,86)=.12, \mathrm{p}=.89, \eta^{2}=.003$, [Table 3].

\section{Accumulation of senescent $T$ cells in hip fracture patients with depressive symptoms}

CD28 is a co-stimulatory molecule involved in $\mathrm{T}$ cell activation which is lost as $\mathrm{T}$ cells progress towards senescence. PBMCs were stained with an anti-CD28 antibody to identify $\mathrm{CD} 28^{-\mathrm{ve}}$ and $\mathrm{CD} 28^{\text {+ve }}$ cells [Figure 2a]. On examining the frequency of circulating $\mathrm{CD} 28^{-\mathrm{ve}} \mathrm{CD} 4$ $T$ cells, we found significant differences between the three groups, $\mathrm{F}(2,62)=5.26, \mathrm{p}=.008, \eta^{2}=.14$, driven by a significant increase in the percentage of $\mathrm{CD} 28^{\text {-ve }} \mathrm{CD} 4 \mathrm{~T}$ cells in hip fracture patients with depressive symptoms compared with healthy controls $(\mathrm{p}=.01)$ and hip fracture patients without depressive symptoms $(\mathrm{p}=.04)$ [Figure $2 \mathrm{~b}$ ]. Similarly, differences in the frequency of circulating CD28 ${ }^{\text {-ve }}$ CD8 $\mathrm{T}$ cells were found between the three groups, $\mathrm{F}(2,62)=8.30, \mathrm{p}=.001, \eta^{2}=.21$, driven by a significant increase in the percentage of $\mathrm{CD} 28^{-\mathrm{ve}} \mathrm{CD} 8 \mathrm{~T}$ cells in hip fracture patients with depressive symptoms compared with healthy controls $(\mathrm{p}=.001)$ and hip fracture patients without depressive symptoms $(\mathrm{p}=.01)$ [Figure $2 \mathrm{~b}$ ].

Table 2 Naive and memory CD4 T lymphocytes in hip fracture patients

\begin{tabular}{|c|c|c|c|c|}
\hline \multirow[t]{2}{*}{ Variable } & \multirow[t]{2}{*}{ Controls } & \multicolumn{3}{|l|}{ Mean (SD) } \\
\hline & & $\mathrm{HF}$ & $H F+D$ & $\mathrm{p}$ \\
\hline Naïve CD4 T cells (\%) & $38.92(19.65)$ & $36.87(20.55)$ & $36.55(18.11)$ & .87 \\
\hline Absolute numbers $\left(10^{6} / \mathrm{ml}\right)$ & $.35(.27)$ & $.22(.22)$ & $.21(.15)$ & .13 \\
\hline CM CD4 T cells (\%) & $3.49(6.99)$ & $3.49(3.37)$ & $5.38(6.98)$ & .40 \\
\hline Absolute numbers $\left(10^{6} / \mathrm{ml}\right)$ & $.01(.01)$ & $.03(.02)$ & $.02(.02)$ & .26 \\
\hline EM CD4 T cells (\%) & $19.38(10.62)$ & $20.33(10.93)$ & $21.39(15.31)$ & .81 \\
\hline Absolute numbers $\left(10^{6} / \mathrm{ml}\right)$ & $.14(.07)$ & $.14(.11)$ & $.10(.08)$ & .46 \\
\hline EMRA CD4 T cells (\%) & $38.40(17.15)$ & $40.10(17.36)$ & $36.96(16.42)$ & .79 \\
\hline Absolute numbers $\left(10^{6} / \mathrm{ml}\right)$ & $.31(.14)$ & $.26(.17)$ & $.22(.10)$ & .16 \\
\hline Total memory CD4 T cells (\%) & $61.07(19.64)$ & $63.16(20.54)$ & $63.44(18.04)$ & .87 \\
\hline Absolute numbers $\left(10^{6} / \mathrm{ml}\right)$ & $.46(.14)$ & $.39(.21)$ & $.34(.15)$ & .12 \\
\hline Naive: memory ratio & $.82(.87)$ & $.87(.84)$ & $.73(.63)$ & .80 \\
\hline
\end{tabular}


Table 3 Naive and memory CD8 T lymphocytes in hip fracture patients

\begin{tabular}{|c|c|c|c|c|}
\hline \multirow[t]{2}{*}{ Variable } & \multirow[t]{2}{*}{ Controls } & \multicolumn{3}{|l|}{ Mean (SD) } \\
\hline & & $\mathrm{HF}$ & $H F+D$ & $p$ \\
\hline Naïve CD8 T cells (\%) & $16.98(16.12)$ & $15.73(13.11)$ & $16.61(13.89)$ & .94 \\
\hline Absolute numbers $\left(10^{6} / \mathrm{ml}\right)$ & $.05(.07)$ & $.02(.04)$ & $.02(.01)$ & .18 \\
\hline CM CD8 T cells (\%) & $26.55(14.61)$ & $33.17(20.09)$ & $32.03(16.01)$ & .26 \\
\hline Absolute numbers $\left(10^{6} / \mathrm{ml}\right)$ & $.06(.06)$ & $.10(.11)$ & $.09(.09)$ & .45 \\
\hline EM CD8 T cells (\%) & $41.04(13.27)$ & $33.40(16.16)$ & $33.56(14.44)$ & .07 \\
\hline Absolute numbers $\left(10^{6} / \mathrm{ml}\right)$ & $.13(.09)$ & $.09(.10)$ & $.09(.08)$ & .30 \\
\hline EMRA CD8 T cells (\%) & $14.44(11.09)$ & $17.02(13.50)$ & $17.63(13.64)$ & .57 \\
\hline Absolute numbers $\left(10^{6} / \mathrm{ml}\right)$ & $.04(.04)$ & $.04(.09)$ & $.02(.02)$ & .60 \\
\hline Total memory CD8 T cells (\%) & $83.01(16.12)$ & $83.99(12.89)$ & $82.43(14.65)$ & .92 \\
\hline Absolute numbers $\left(10^{6} / \mathrm{ml}\right)$ & $.27(.20)$ & $.21(.16)$ & $.19(.19)$ & .39 \\
\hline Naive: memory ratio & $.26(.41)$ & $.23(.26)$ & $.28(.45)$ & .89 \\
\hline
\end{tabular}

When the above analyses were repeated with adjustment for age, sex and BMI, the results remained significant (data not shown).

To further investigate possible increases in senescent $\mathrm{T}$ cells in hip fracture patients other markers of senescence were examined, such as CD57 [33]. On examining CD57 expression [Figure 2c], we found significant differences in CD57 ${ }^{\text {tve }} \mathrm{CD} 4 \mathrm{~T}$ cells, $\mathrm{F}(2,62)=1.32, \mathrm{p}=.008$, $\eta^{2}=.16$ between the three groups [Figure $2 \mathrm{~d}$ ], driven by an increase in the percentage of $\mathrm{CD} 57^{\text {tve }} \mathrm{T}$ cells in hip fracture patients with depressive symptoms compared with healthy controls $(\mathrm{p}=.003)$. Similarly, differences in frequency of circulating $\mathrm{CD} 57^{+\mathrm{ve}} \mathrm{CD} 8 \mathrm{~T}$ cells were seen between our three groups, $\mathrm{F}(2,62)=8.16$, $\mathrm{p}=.001, \eta^{2}=.20$, driven by a significant increase in the percentage of $\mathrm{CD} 57^{+\mathrm{ve}} \mathrm{CD} 8 \mathrm{~T}$ cells in hip fracture patients with depressive symptoms compared with healthy controls $(\mathrm{p}=.001)$ [Figure $2 \mathrm{~d}$ ]. When the above analyses were repeated with adjustment for age, sex and BMI, the results remained significant (data not shown).

Finally, on examining frequency of $\mathrm{CD} 28^{\text {-ve }} \mathrm{CD} 57^{\text {tve }}$ CD4 $\mathrm{T}$ cells significant differences, $\mathrm{F}(2,56)=6.28$, $\mathrm{p}=.003, \eta^{2}=.18$ occurred [Additional file 1: Figure S1a], due to increased frequency of $\mathrm{CD} 28^{-\mathrm{ve}} \mathrm{CD} 57^{\text {ve }} \mathrm{CD} 4 \mathrm{~T}$ cells in hip fracture patients with depressive symptoms compared with healthy controls, $\mathrm{p}=.002$, but not on comparison with hip fracture patients without depressive symptoms, $\mathrm{p}=.13$. Similarly, the frequency of $\mathrm{CD} 28^{\text {-ve }}$ $\mathrm{CD}^{2} 7^{\text {ve }} \mathrm{CD} 8 \mathrm{~T}$ cells were also significantly different, $\mathrm{F}(2,56)=4.12, \mathrm{p}=.02, \eta^{2}=.12$ between the three groups [Additional file 1: Figure $\mathrm{S} 1 \mathrm{~b}$ ], due to a significant increase in frequency of $\mathrm{CD} 28^{\text {-ve }} \mathrm{CD} 57^{\text {+ve }} \mathrm{CD} 8 \mathrm{~T}$ cells in hip fracture patients with depressive symptoms compared with healthy controls, $\mathrm{p}=.02$ but not in comparison with hip fracture patients without depressive symptoms, $\mathrm{p}=.49$.
Killer cell lectin like receptor G 1(KLRG1) has also been identified as a marker for functional senescence in $\mathrm{T}$ cells [34]. On examining KLRG1 expression on T cells [Figure 3a], no significant differences were reported in the frequency of $\mathrm{KLRG}^{+\mathrm{ve}} \mathrm{CD} 4 \mathrm{~T}$ cells, $\mathrm{F}(2,55)=2.53$, $\mathrm{p}=.09, \eta^{2}=.08$ between the three groups [Figure $3 \mathrm{~b}$ ]. However, significant differences were seen in the percentage of KLRG1 $1^{\text {+ve }} \mathrm{CD} 8 \mathrm{~T}$ cells between our groups, $\mathrm{F}(2,55)=3.91, \mathrm{p}=.02, \eta^{2}=.12$, driven by an increase in hip fracture patients with depressive symptoms compared with healthy controls $(\mathrm{p}=.03)$.

Elevated levels of Programmed cell death (PD-1) receptor is also a hallmark of $\mathrm{T}$ cell dysfunction termed $\mathrm{T}$ cell exhaustion [35]. $\mathrm{T}$ cell exhaustion is characterised by a loss of effector T cell function, including cytokine production, reduced proliferation capacity and ex vivo killing [36]. Limited studies examining PD-1 with age have reported an increase in PD-1 expression on the T cells of aged mice $[37,38]$. In this study we report for the first time significant differences in peripheral $\mathrm{PD} 1^{\text {+ve }} \mathrm{CD} 4 \mathrm{~T}$ cells [Figure 3c], $\mathrm{F}(2,62)=4.72, \mathrm{p}=.01, \eta^{2}=.13$ and peripheral $\mathrm{PD}^{\text {+ve }} \mathrm{CD} 8 \mathrm{~T}$ cells, $\mathrm{F}(2,62)=3.11, \mathrm{p}=.05, \eta^{2}=.09$ between the three groups [Figure 3d], driven by an increase in the percentage of $\mathrm{PD} 1^{\text {+ve }} \mathrm{CD} 4 \mathrm{~T}$ and $\mathrm{PD} 1^{+\mathrm{ve}} \mathrm{CD} 8$ $\mathrm{T}$ cells in hip fracture patients with depressive symptoms compared with healthy controls, $\mathrm{p}=.01$ and $\mathrm{p}=.05$ respectively.

\section{Accumulation of activated T cells in hip fracture patients with depressive symptoms}

The expression of different activation markers CD69 (early), CD25 (middle) and HLADR (late) on T cells was also examined [Figure 4a]. Firstly, on examining expression of CD69 on CD4 T cells no significant differences were observed between the three groups, $\mathrm{F}(2,64)=1.51$, $\mathrm{p}=.003, \eta^{2}=.16$ [Figure $4 \mathrm{~b}$ ], though significant differences 


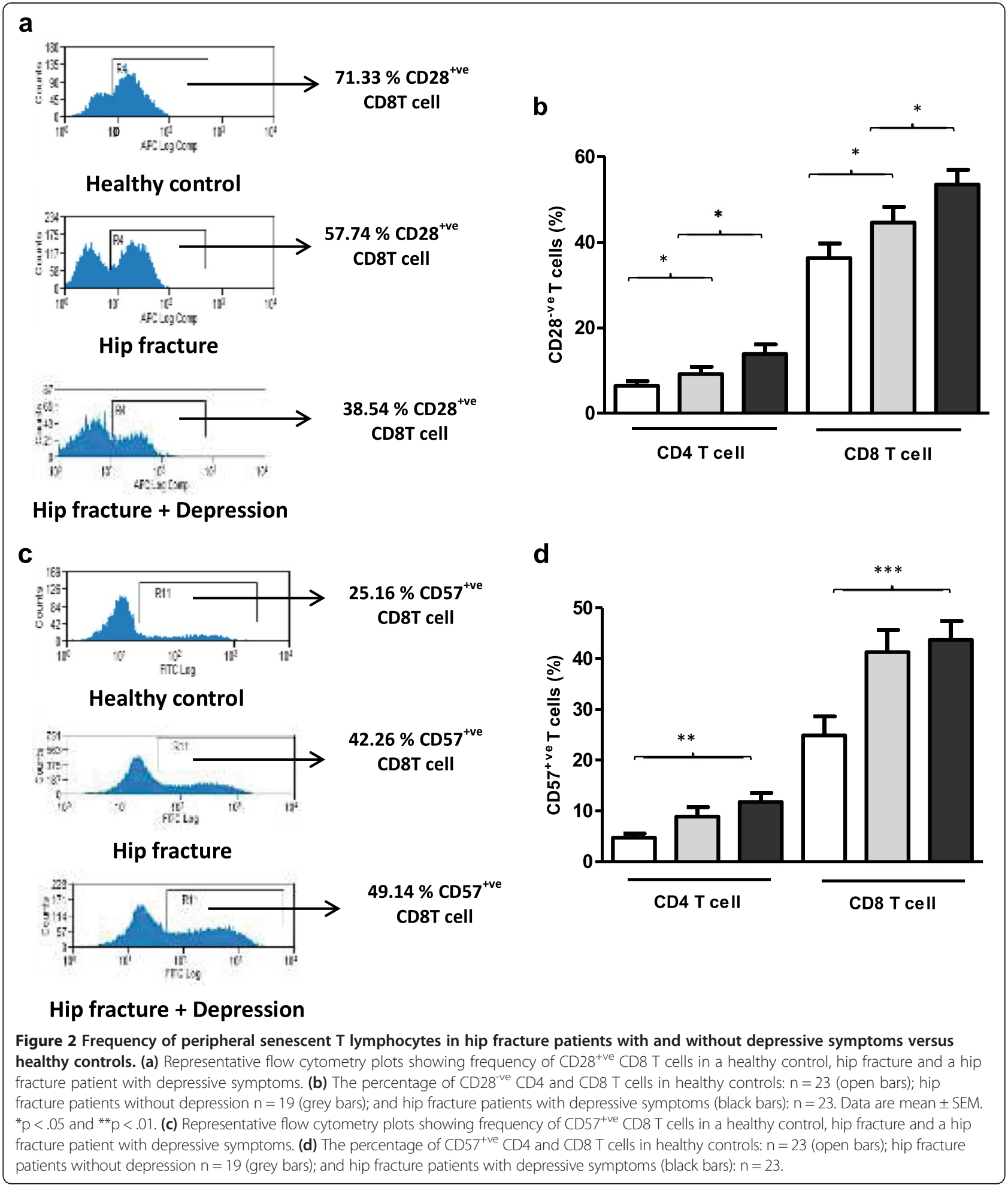

were observed for CD8 T cells, $F(2,64)=5.45, p=.006$, $\eta^{2}=.14$, driven by an increase in the percentage of CD69 ${ }^{\text {tve }} \mathrm{CD} 8 \mathrm{~T}$ cells in hip fracture patients with depressive symptoms compared with healthy controls $(\mathrm{p}=.005)$.
On examining peripheral distribution of $\mathrm{CD} 25^{\text {+ve }} \mathrm{CD} 4$ $\mathrm{T}$ cells and $\mathrm{CD} 25^{+\mathrm{ve}} \mathrm{CD} 8 \mathrm{~T}$ cells no significant differences were found, $\mathrm{F}(2,53)=1.30, \mathrm{p}=.28, \eta^{2}=.04$ (data not shown). Similarly the frequency of HLADR expressing CD4 T cells [Figure 4c] was not different between 


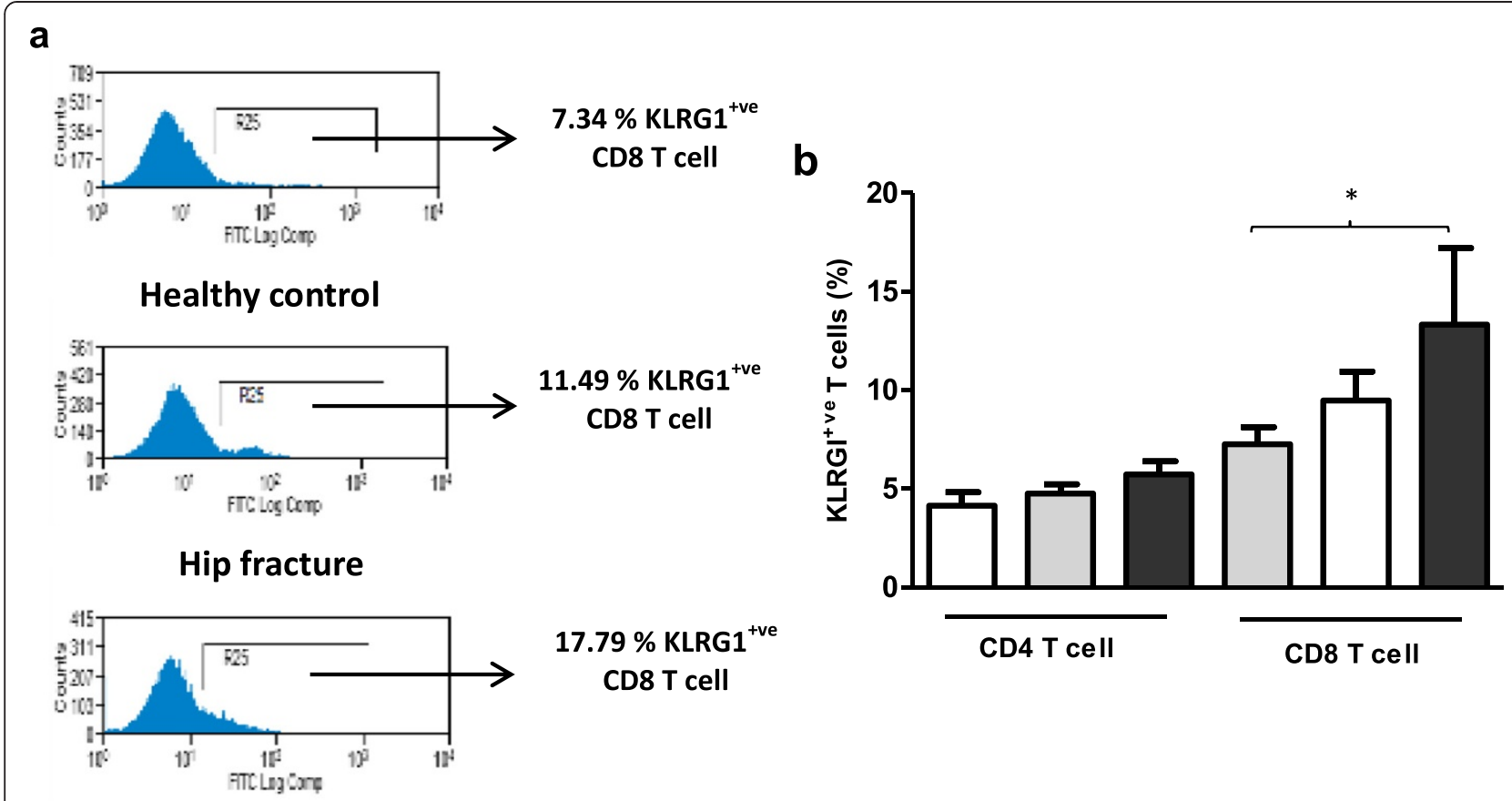

Hip fracture + Depression

C

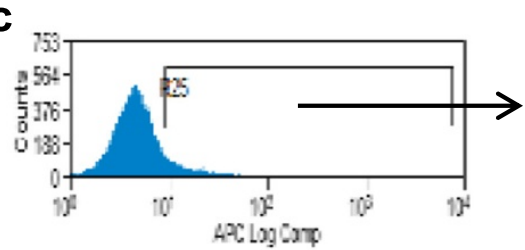

Healthy control

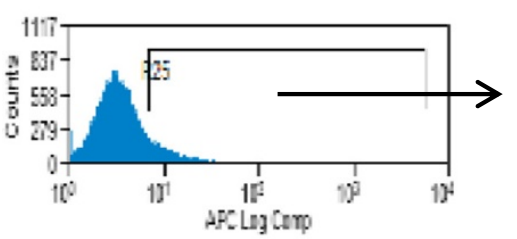

Hip fracture

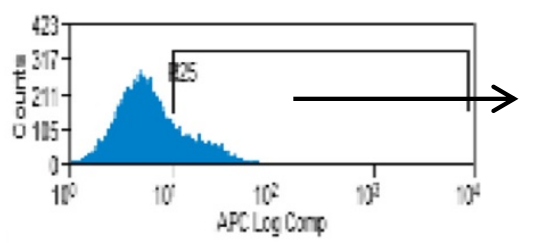

$12.81 \% \mathrm{PD}^{\text {+ve }}$ CD8 T cell

$21.93 \% \mathrm{PD}^{\text {+ve }}$ CD8 $T$ cell

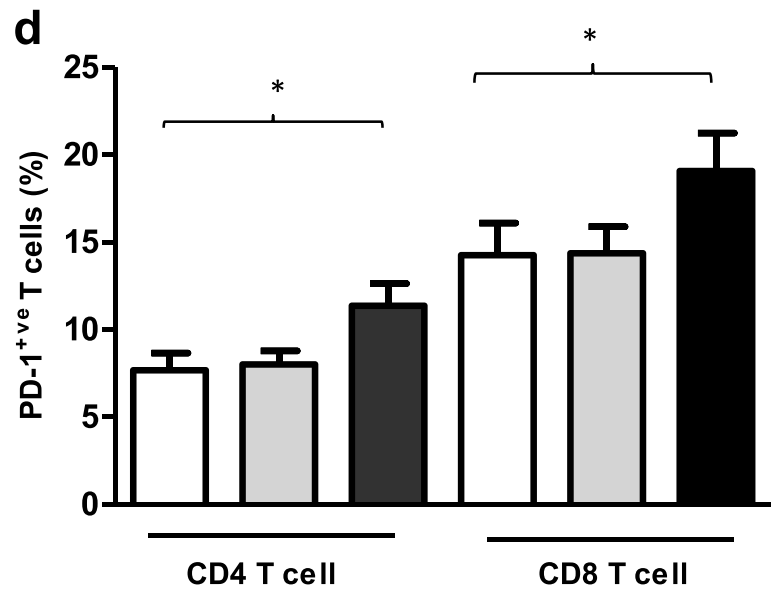

Hip fracture + Depression

Figure $\mathbf{3}$ (See legend on next page.) 
(See figure on previous page.)

Figure 3 Frequency of peripheral senescent and exhausted T lymphocytes in hip fracture patients with and without depressive symptoms versus healthy controls. (a) Representative flow cytometry plots showing frequency of KLRG1 ${ }^{\text {+ve }} \mathrm{CD} 8 \mathrm{~T}$ cells in a healthy control, hip fracture and a hip fracture patient with depressive symptoms. (b) The percentage of KLRG1 $1^{\text {+ve }}$ CD4 and CD8 T cells in healthy controls: $n=23$ (open bars); hip fracture patients without depression $n=19$ (grey bars); and hip fracture patients with depressive symptoms $n=23$ (black bars). (c) Representative flow cytometry plots showing frequency of PD1 $1^{\text {+ve }} \mathrm{CD} 8 \mathrm{~T}$ cells in a healthy control, hip fracture and a hip fracture patient with depressive symptoms. (d) The percentage of PD1 ${ }^{\text {+ve }}$ CD4 and CD8 T cells in healthy controls: $n=23$ (open bars); hip fracture patients without depression $n=19$ (grey bars); and hip fracture patients with depressive symptoms $n=23$ (black bars). Data are mean \pm SEM. ${ }^{*} p<.05$ and ${ }^{* *} p<.01$.

our three groups, $\mathrm{F}(2,60)=2.87, \mathrm{p}=.06, \eta^{2}=.08$ [Figure 4d], though we did find significant differences in the frequency of peripheral HLADR ${ }^{+v e}$ CD8 T cells, $\mathrm{F}(2,60)=13.58, \mathrm{p}<.001, \eta^{2}=.31$ between our three groups [Figure $4 \mathrm{~d}$ ], driven by an increase in the percentage of HLADR ${ }^{+v e}$ CD8 T cells in hip fracture patients with depressive symptoms compared with healthy controls $(\mathrm{p}<.001)$. When the above analyses were repeated with adjustment for age, sex and BMI, the results still remained significant (data not shown).

\section{Th1/Th2/Th17 balance}

To compare functional activity of $\mathrm{T}$ cells between healthy controls and hip fracture patients, the balance of IFN $\gamma^{+ \text {ve }}$ (Th1): IL4 ${ }^{+v e}$ (Th2) and IL17 ${ }^{+v e}$ (Th17) CD4 T cells was investigated post stimulation with PMA and Ionomycin. In this study, no significant differences were found in the Th1 / Th2 ratio between the three groups $\mathrm{F}(2,59)=1.49, \mathrm{p}=.23, \eta^{2}=.04$ [Figure 5a]. The frequency of $\mathrm{IL}_{1} 7^{\text {ve }} \mathrm{CD} 4 \mathrm{~T}$ cells post-stimulation with PMA and Ionomycin was not significantly different between our three groups $\mathrm{F}(2,37)=.93, \mathrm{p}=.40, \eta^{2}=.04$ [Figure 5b]. Further, measuring circulating serum levels of IL17, revealed no significant differences between healthy controls and hip fracture patients with and without depression $\mathrm{F}(2,63)=.36, \mathrm{p}=.69, \eta^{2}=.01$.

\section{Pro-inflammatory cytokine production by T cells in hip fracture patients}

On comparing the frequency of IL6 ${ }^{+v e}$ CD4 T cells [Figure 5c] post-stimulation with PMA and Ionomycin, significant differences were found between our three groups $F(2,57)=3.47, p=.03, \eta^{2}=.10$, driven by an increase in percentage of IL6 ${ }^{\text {tve }}$ CD4 T cells in hip fracture patients with depressive symptoms compared with healthy controls, $\mathrm{p}=.04$, no significant differences were observed between hip fracture patients with and without depressive symptoms, $\mathrm{p}=.17$ [Figure $5 \mathrm{~d}$ ]. The frequency of $\mathrm{TNF}^{+\mathrm{ve}} \mathrm{CD} 4 \mathrm{~T}$ cells [Figure $5 \mathrm{c}$ ] post-stimulation with PMA and Ionomycin, showed significant differences between our three groups $\mathrm{F}(2,58)=3.49, \mathrm{p}=.03$, $\eta^{2}=.10$, driven by an increase in percentage of $\mathrm{TNF}^{+\mathrm{ve}}$ CD4 $\mathrm{T}$ cells in hip fracture patients with depressive symptoms compared with healthy controls, $\mathrm{p}=.03$ [Figure 5e].

\section{GDS scores and T cell phenotype}

For several measures of $\mathrm{T}$ cell numbers or phenotype there was an effect of depression not seen in patients with hip fracture alone. To see if there was a graded association between depressive symptoms and $\mathrm{T}$ cells in these patients linear regression analysis was performed. In relation to senescent $T$ cells there was an association between GDS scores and the frequency of peripheral $\mathrm{CD}^{\text {+ve }}{ }^{\text {e }}$ 44 T cells, $\mathrm{r}(42)=.42, \mathrm{p}=.006$ [Figure 6a], though no significant association was found for CD57 $7^{\text {ve }}$ CD8 T cells, $\mathrm{r}(42)=.15, \mathrm{p}=.32$. There was also a trend towards an accumulation of $\mathrm{KLRG}^{+\mathrm{ve}} \mathrm{T}$ cells in hip fracture patients with higher GDS scores, but this did not reach statistical significance for the frequency of $\mathrm{KLRG}^{+\mathrm{ve}}$ CD4 T cells, $\mathrm{r}(39)=.29, \mathrm{p}=.06$, or $\mathrm{KLRG} 1^{+\mathrm{ve}}$ CD8 $\mathrm{T}$ cells, $\mathrm{r}(39)=.28, \mathrm{p}=.07$. There was no significant association between GDS scores and the frequency of peripheral CD28-ve CD4 T cells, $r(42)=.19, \mathrm{p}=.22$, but there was an association between GDS scores and peripheral CD28 ${ }^{-v e}$ CD8 $\mathrm{T}$ cells, $\mathrm{r}(42)=.30, \mathrm{p}=.04$ [Figure 6b]. There was no significant association observed between GDS scores and the frequency of CD69 ${ }^{\text {+ve }}$ CD8 $\mathrm{T}$ cells, $\mathrm{r}(46)=.17, \mathrm{p}=.25$, or HLADR ${ }^{+\mathrm{ve}} \mathrm{CD} 8 \mathrm{~T}$ cells, $\mathrm{r}(42)=.16, \mathrm{p}=.31$ in hip fracture patients. There was also a significant association between GDS scores and thefrequency of $\mathrm{PD} 1^{\text {+ve }} \mathrm{CD} 4 \mathrm{~T}$ cells, $\mathrm{r}(41)=.34, \mathrm{p}=.02$ [Figure 6c]. Interestingly, a significant association was found between circulating IL6 levels and the frequency of senescent CD57 ${ }^{+v e}$ CD4 $T$ cells, $\mathrm{r}(63)=.39, \mathrm{p}=.04$ [Figure $6 \mathrm{~d}$ ], such that patients with higher serum levels of IL6 had a higher frequency of circulating CD $57^{\text {ve }}$ CD4 T cells.

\section{Cortisol and T cell phenotype}

Cortisol is known to induce apoptosis in T cells, therefore we determined whether there was an association between serum cortisol levels and $\mathrm{T}$ cell numbers. However, no association was observed between serum cortisol levels and frequency of circulating $\mathrm{T}$ cells $(\beta=-.17, \mathrm{p}=.18$, $\left.\Delta \mathrm{R}^{2}=.03\right)$, absolute $\mathrm{T}$ cell numbers $(\beta=-.20, \mathrm{p}=.27$, $\left.\Delta \mathrm{R}^{2}=.04\right)$, frequency of activated CD69 ${ }^{+\mathrm{ve}} \mathrm{CD} 8 \mathrm{~T}$ cells $\left(\beta=.16, \quad \mathrm{p}=.22, \Delta \mathrm{R}^{2}=.02\right), \mathrm{HLADR}^{+\mathrm{ve}}$ CD8 $\mathrm{T}$ cells $\left(\beta=.22, p=.11, \Delta R^{2}=.04\right)$, senescent $C D 28^{-v e} \operatorname{CD} 8 \mathrm{~T}$ cells $\left(\beta=-.04, p=.72, \Delta R^{2}=.002\right), C D 57^{\text {ve }}$ CD8 T cells $\left(\beta=-.04, p=.74, \Delta \mathrm{R}^{2}=.002\right), \mathrm{KLRG}^{\text {+ve }} \mathrm{CD} 8 \mathrm{~T}(\beta=.18$, 


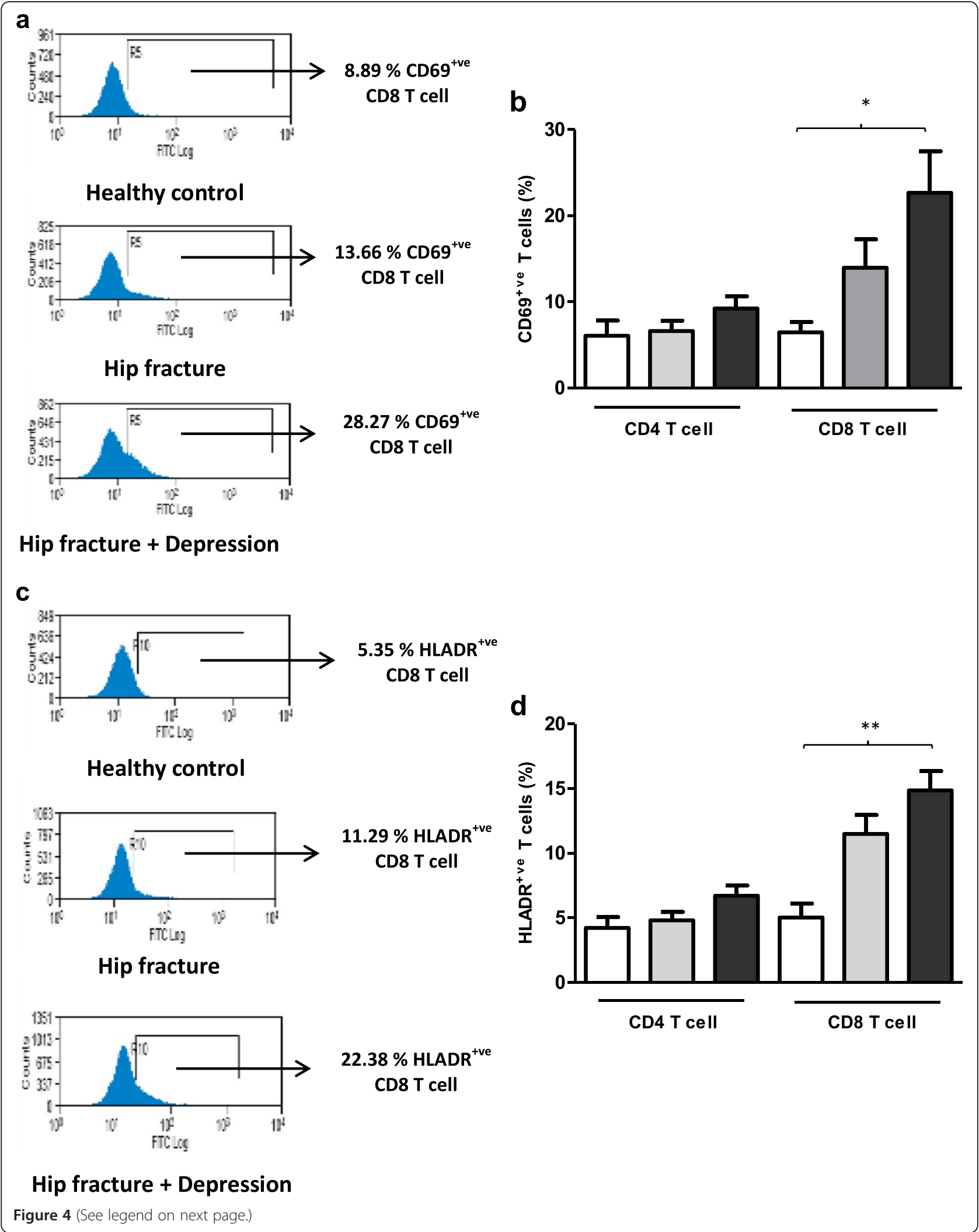


(See figure on previous page.)

Figure 4 Frequency of peripheral activated $\mathrm{T}$ lymphocytes in hip fracture patients with and without depressive symptoms versus healthy controls. (a) Representative flow cytometry plots showing frequency of CD69 ${ }^{\text {+ve }} \mathrm{CD} 8 \mathrm{~T}$ cells in a healthy control, hip fracture and a hip fracture patient with depressive symptoms. (b) The percentage of $C D 69^{\text {+ve }} \mathrm{CD} 4$ and CD8 T cells in healthy controls: $\mathrm{n}=21$ (open bars); hip fracture patients without depression: $n=22$ (grey bars) and hip fracture patients with depressive symptoms: $n=24$ (black bars). (c) Representative flow cytometry plots showing frequency of HLADR ${ }^{+v e}$ CD8 T cells in a healthy control, hip fracture and a hip fracture patient with depressive symptoms. (d) The percentage of HLADR ${ }^{+v e}$ CD4 and CD8 T cells in healthy controls: $n=21$ (open bars); hip fracture patients without depression: $\mathrm{n}=22$ (grey bars) and hip fracture patients with depressive symptoms: $\mathrm{n}=24$ (black bars). Data are mean \pm SEM. ${ }^{*} \mathrm{p}<.01$ and ${ }^{* *} \mathrm{p}<.001$.

$\left.\mathrm{p}=.20, \Delta \mathrm{R}^{2}=.03\right), \mathrm{PD}^{\text {+ve }} \mathrm{CD} 4 \mathrm{~T}$ cells $(\beta=.07, \mathrm{p}=.62$, $\left.\Delta \mathrm{R}^{2}=.005\right)$, or $\mathrm{PD} 1^{+\mathrm{ve}} \mathrm{CD} 8 \mathrm{~T}$ cells $(\beta=.28, \mathrm{p}=.07$, $\Delta \mathrm{R}^{2}=.09$ ) in hip fracture patients.

\section{Cytokines and T cell phenotype}

A significant association was found between circulating IL6 levels and the frequency of senescent $\mathrm{CD} 28^{\text {-ve }} \mathrm{CD} 57^{\text {+ve }}$ $\mathrm{T}$ cells, $\beta=.37, \mathrm{p}=.01, \Delta \mathrm{R}^{2}=.13$, such that patients with higher serum levels of IL6 had a higher frequency of circulating $\mathrm{CD}_{2} 8^{\text {-ve }} \mathrm{CD} 57^{\text {tve }}$ T cells [Additional file 1: Figure S2a]. A similar association was observed between serum TNF $\alpha$ levels and the frequency of $\mathrm{CD} 28^{-\mathrm{ve}} \mathrm{CD} 57^{\text {tve }} \mathrm{T}$ cells, $\beta=.44, \mathrm{p}=.01, \Delta \mathrm{R}^{2}=.19$ [Additional file 1: Figure $\mathrm{S} 2 \mathrm{~b}$ ].

\section{Discussion}

Depression is a common public health problem that has been identified by the World Health Organisation as a leading cause of disability worldwide [39]. Depression in addition to being a psychiatric disorder has also been associated with a state of immune dysfunction [40]. In the present study, we have reported that new onset depression results in both phenotypic and functional alteration in peripheral $\mathrm{T}$ cells in elderly hip fracture patients.

Firstly, we report a decline in T cell frequency and absolute numbers in hip fracture patients with depressive symptoms compared with healthy controls, which is in agreement with previous reports of reduced circulating $\mathrm{T}$ cells in depressed individuals [41,42]. Although the exact mechanism responsible has not been explored in this manuscript, a few possibilities can be proposed. Exposure to chronic stress is accompanied by increased HPA axis activity $[43,44]$. Glucocorticoids are known inducers of $\mathrm{T}$ cell apoptosis [45]. We have previously reported elevated serum cortisol levels in hip fracture patients with depressive symptoms [31]. However, there was no association between circulating $\mathrm{T}$ cell numbers and serum cortisol levels, suggesting that additional mechanisms may be responsible for the reduction in circulating $\mathrm{T}$ cells in hip fracture patients with depressive symptoms.

Evaluation of $\mathrm{T}$ cell subsets revealed that the proportion of $\mathrm{CD} 4$ and $\mathrm{CD} 8 \mathrm{~T}$ cells and the CD4:CD8 ratio did not differ between hip fracture patients with and without depressive symptoms and healthy controls. These findings are in line with previous reports showing that the
CD4:CD8 ratio was unaltered in depressed individuals [46,47]. Furthermore, hip fracture alone or in synergy with depressive symptoms did not have an effect on the naïve: memory ratio of $\mathrm{T}$ cells suggesting that this stress did not further exacerbate the age-related decline in naive $\mathrm{T}$ cells or expansion of the memory $\mathrm{T}$ cell pool. These findings contradict a previous study reporting an increase in memory $\mathrm{T}$ cells in depressed patients $[48,49]$. This discrepancy might be due to the differences in cell surface markers used to identify memory $\mathrm{T}$ cells as Maes et al. identified memory $\mathrm{T}$ cells as CD45RA ${ }^{\text {ve }} \mathrm{T}$ cells, whereas in this study both CD45RA and CCR7 were used to identify $\mathrm{T}$ cell subsets. In addition our patients did not suffer from chronic depression and their condition was acute in response to their injury.

It is well documented that ageing is accompanied by an accumulation of senescent T cells. On examining the additional effect of chronic stress on CD28 expression, a significant increase in the percentage of $\mathrm{CD} 28^{\text {-ve }} \mathrm{T}$ cells was seen, especially in CD8 $\mathrm{T}$ cells in hip fracture patients with depressive symptoms. Moreover, an increase in $\mathrm{CD} 57^{\text {ve }} \mathrm{T}$ cells, again most marked in CD8 T cells, was also observed in hip fracture patients with depressive symptoms, which is in line with previous studies in depressed individuals [49]. Interestingly, poor mental health associated with reduced job satisfaction has also been characterised by an increase in $\mathrm{CD} 57^{\text {+ve }} \mathrm{CD} 8 \mathrm{~T}$ cells [50]. The majority of the CD $57^{\text {ve }} \mathrm{T}$ cells are also $\mathrm{CD} 28^{-v}$ [51], therefore it is not surprising that an accumulation of $\mathrm{CD} 28^{-\mathrm{ve}} \mathrm{CD} 57^{\text {tve }} \mathrm{T}$ cells was seen in hip fracture patients with depressive symptoms and this is in agreement with similar findings in depressed individuals [52]. The accumulation of these expanded T cells could reduce the $\mathrm{T}$ cell repertoire in hip fracture patients with new onset of depression and reduce their immune response towards novel pathogens and vaccines $[53,54]$.

Although the exact mechanism responsible for accumulation of senescent $\mathrm{T}$ cells has not been explored in this manuscript, a few possibilities can be proposed. TNFa is known to induce down regulation of CD28 expression on $\mathrm{T}$ cells [55]. In this study we found a correlation between circulating $\mathrm{CD} 28^{-\mathrm{ve}} \mathrm{CD} 57^{\text {+ve }} \mathrm{T}$ cells and serum IL6 and TNF $\alpha$ levels, suggesting the contribution of the pro-inflammatory environment in accumulation of senescent $\mathrm{T}$ cells. Further, CMV seropositivity 
a

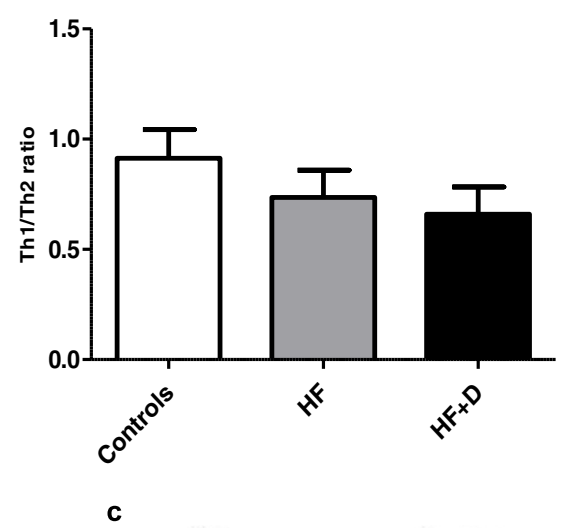

b

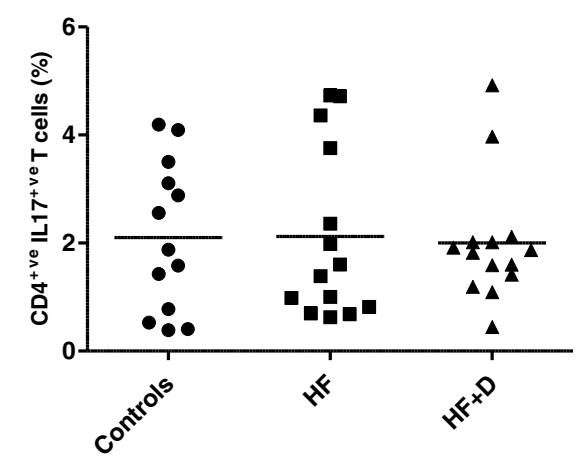

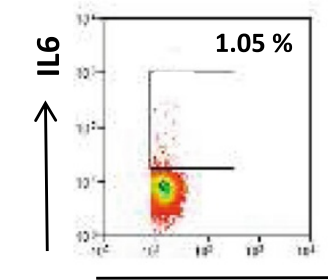
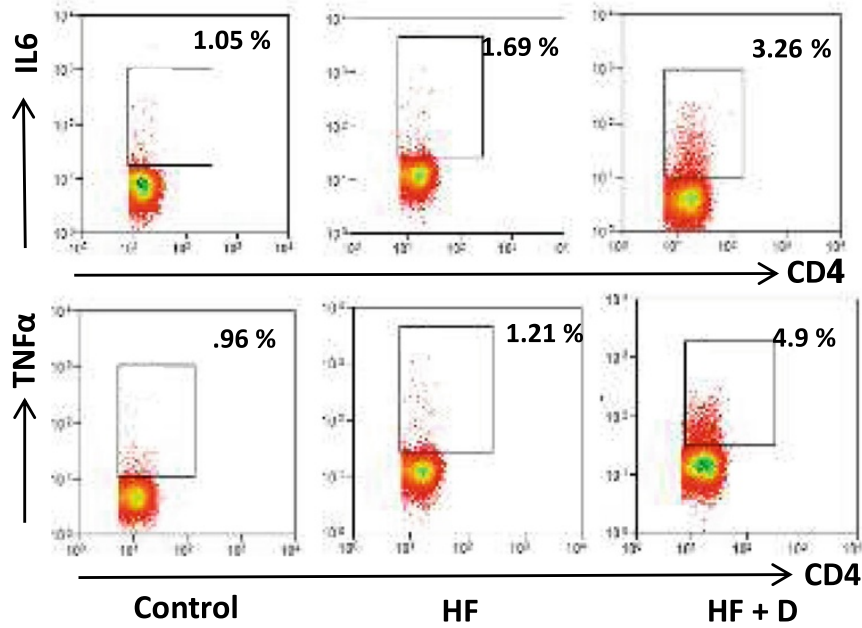

Control

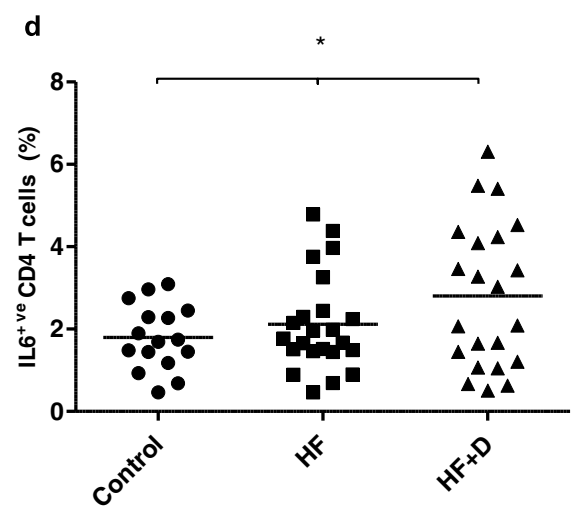

HF

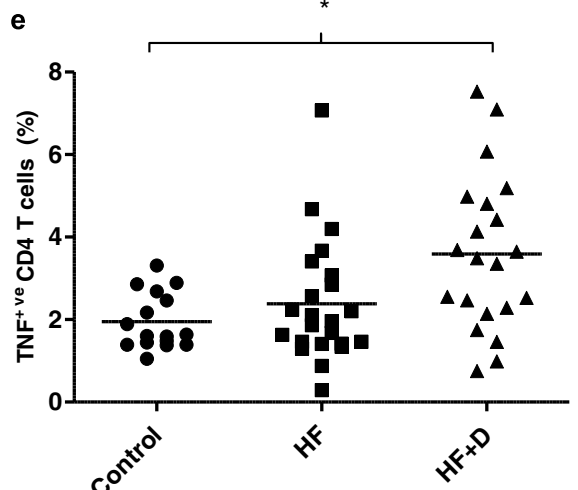

Figure $\mathbf{5}$ Cytokine production by $\mathbf{T}$ lymphocytes in hip fracture patients. (a) The Th1 (IFNY ${ }^{+v e}$ ) / Th2 (IL $4^{+v e}$ ) ratio, or (b) the percentage of IL $17^{+v e}$ CD4 T cells in healthy controls, $n=16$; hip fracture patients without depression (HF), $n=21$; and hip fracture patients with depressive symptoms $(H F+D), n=21$. The solid bar represents the mean value. (c) Representative flow cytometry plots showing frequency of IL $6^{\text {tve }} \mathrm{CD4}$ (upper panel) and TNFa+ve $\mathrm{T}$ cells (lower panel) in a healthy control, hip fracture and a hip fracture patient with depressive symptoms. (d) The percentage of IL $6^{\text {+ve }}$ CD4 T cells or (e) TNFa ${ }^{+v e} T$ cells in healthy controls, $n=16$; hip fracture patients without depression (HF), $n=23$; and hip fracture patients with depressive symptoms $(H F+D), n=22$. The solid bar represents the mean value. The solid bar represents the mean value. ${ }^{*} \mathrm{p}<.05$ and ${ }^{* *} \mathrm{p}<.01$.

has also been associated with senescence in the T cell compartment and accumulation of late differentiated $\mathrm{CD} 28^{\text {-ve }}$ $\mathrm{CD}^{2} 7^{\text {tve }} \mathrm{T}$ cells [56,57]. Although, CMV seropositivity has not been tested in our hip fracture patients, it is possible that there might be an association between CMV and accumulation of senescent $\mathrm{T}$ cells in hip fracture patients.

In addition to being an inflammatory disorder, depression is also characterised by activation of cell-mediated 

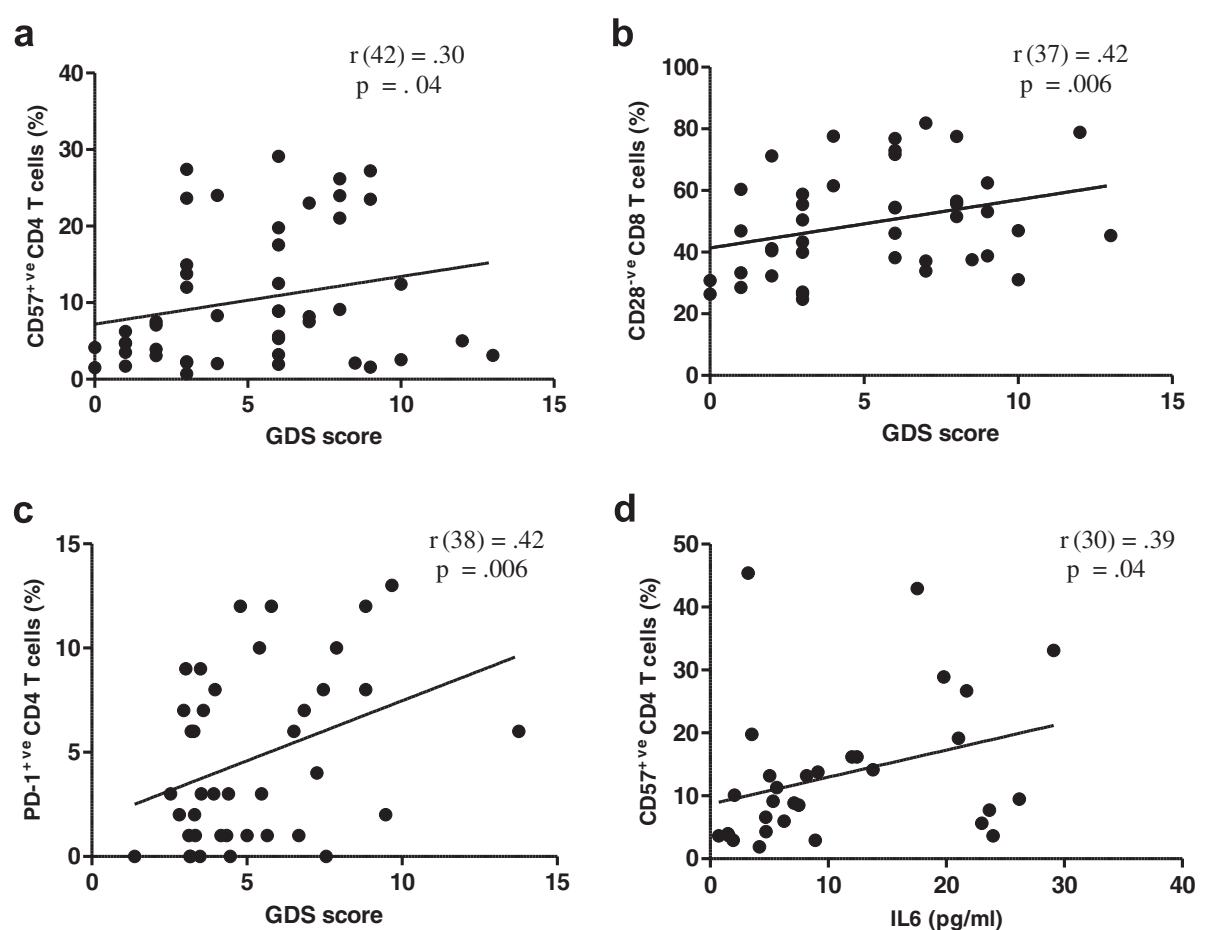

Figure 6 Association between senescent T cells and depressive symptom score (GDS) and circulating pro-inflammatory cytokine IL6. Correlation between (a) GDS score and circulating CD57 ${ }^{\text {ve }}$ CD4 T cells $(n=41)$, (b) GDS score and circulating CD28 $8^{\text {-ve }}$ CD8 T cells ( $\left.n=37\right)$, (c) GDS and circulating PD1 ${ }^{+v e}$ CD4 T cells $(n=38)$, or (d) IL6 levels and circulating CD57 ${ }^{\text {tve }}$ CD4 T cells $(n=30)$.

immunity [58]. Although we failed to report signs of monocyte activation in hip fracture patients with depressive symptoms [59], an increase in T cells expressing the activation markers CD69 and HLADR was seen in hip fracture patients with depressive symptoms. These findings are consistent with previous reports of increased activated $\mathrm{HLADR}^{+\mathrm{ve}} \mathrm{T}$ cells in depressed individuals $[48,60,61]$. Overall, our data point towards the existence of a state of immune activation in individuals with depressive symptoms.

Next, on exploring $\mathrm{T}$ cell functional properties in hip fracture patients we found no significant differences in Th1 (IFNY)/Th2 (IL4) balance between our hip fracture patients with and without depression. Previous findings have associated depressed mood [62] with a shift in the Th1/Th2 balance towards a Th2 response, in this study we did observe a trend towards an increase in Th2 cells (IL4 ${ }^{\text {+ve }}$ CD4 $\mathrm{T}$ cells) but it did not reach statistical significance. Ageing is also accompanied by a skewing towards a Th17 phenotype [63] and a similar increase in Th17 cells has been reported in patients with major depressive symptoms [64]. However, in this study no such increase in Th17 producing CD4 T cells was observed in hip fracture patients with depressive symptoms post stimulation.

Depression has been characterised as an increased inflammatory status (inflammaging) including elevated levels of pro-inflammatory cytokines, including IL6, TNF $\alpha$ and IL1 $\beta[65,66]$. We have previously reported that elevated levels of TNF $\alpha$ and IL6 were seen in hip fracture patients with depressive symptoms compared with patients without depressive symptoms and healthy controls [31]. On examining pro-inflammatory cytokine production by $T$ cells, we found that hip fracture patients with depressive symptoms had a higher capacity to produce proinflammatory cytokines upon stimulation. Our findings are consistent with the reports of elevated IL6 production post-stimulation in depressed patients [67]. These findings are also in line with previous reports of elevated TNFa production by peripheral blood mononuclear cells in depressed patients [68].

\section{Conclusions}

The present study reports for the first time that development of depressive symptoms in older hip fracture patients can result in phenotypic alteration in $\mathrm{T}$ cells and dysregulated cytokine production. Importantly, these findings suggest that development of depressive symptoms after a hip fracture in older adults is an important driver of immune dysregulation. The clinical significance of these results still remains unexplored, but our findings support the need for preventing and treating depression and depressive symptoms to improve outcomes in older hip fracture patients. 


\section{Methods}

Participants

101 older hip fracture patients (37 male) were recruited from five hospitals in Birmingham, UK between 2010 and 2012. Inclusion criteria were that participants had to be aged 60 years and over with a hip fracture sustained 4-6 weeks previously but with no chronic immunerelated disorders e.g., cancer, diabetes, or taking any regular medications that might modify immunity, e.g., immunosuppressants, statins. Additionally patients must not have had any diagnosis of depression by a physician prior to age 50 years or be taking or have previously taken anti-depressant medication. 43 healthy older adults (26 female), were also recruited from the community as controls. The study was approved by South Birmingham Local Research Ethics Committee and all participants provided written informed consent (study ref: 09/H1203/80).

\section{Study design}

The study design and patient demographics have been reported in full previously [69]. Briefly, the study was a prospective case-control design with three groups of older adults: hip fracture patients with or without depressive symptoms and healthy older adults. Consent was gained whilst patients were still in hospital. All patients provided a blood sample and completed questionnaires and structured interviews 4-6 weeks after hip fracture. Control participants attended the University to provide a single blood sample and complete a depression and anxiety symptoms scale questionnaire and provide basic demographic information. Blood samples were taken between 09.00 and 11.00 to minimise any effect of diurnal variations in steroid or cytokine levels. None of the participants had an acute infection at the time of blood sampling.

\section{Questionnaires}

Standard socio-demographic and health behaviour information were taken and medications, prescription and over-the-counter, were recorded by the interviewer. The psychological status of the participant was assessed by means of standardised psychometric questionnaires. Depression was evaluated by a Geriatric Depression Scale (GDS) [70]. Depression was defined as a GDS score greater than or equal to 6. The Hospital Anxiety and Depression Scale (HADS) was also used to measure depression and anxiety [71]. The scale contains 14 items, scored from 0 (not present) to 3 (considerable), with seven assessing aspects of depression and seven assessing anxiety. Healthy control participants completed the HADS depression sub-scale in order to check that they did not have significant depressive symptoms. A cut-off of $\geq 8$ has previously been used to indicate possible depression [72].

\section{Isolation of PBMCs and immunostaining for analysis of $T$ cell subsets}

PBMCs were isolated from peripheral blood by density centrifugation using Ficoll-Paque ${ }^{\mathrm{Tm}}$ PLUS (GE Healthcare, Uppsala, Sweden). The blood was layered on top of $6 \mathrm{ml}$ Ficoll in a $25 \mathrm{ml}$ universal tube and centrifuged at $650 \times \mathrm{g}$ for 30 minutes with no break. Post centrifugation, the mononuclear cell layer containing PBMC was removed and added to a new universal tube and the cells were washed twice with PBS and counted using a haemocytometer. PBMCs were frozen down by re-suspending cells in freezing medium consisting of 10\% DMSO (Sigma Aldrich, UK) in heat inactivated fetal calf serum (Biosera, UK) and transferring them in small aliquots into cryovials. The cryovials were transferred into a freezing container (Mr Frosty, Sigma Aldrich, UK) containing isopropanol (VWR International, UK) and the frozen cells were then stored at $-80^{\circ} \mathrm{C}$.

For phenotypic characterisation of $\mathrm{T}$ cells, isolated PBMCs were stained with a combination of fluorochrome conjugated antibodies including; anti-human CD3-PEcy7 (eBiosciences; clone:UCHT1), anti-human CD4 Alexa fluor 450 (Biolegend; clone:RPA-T4), anti-human CD8 PE (Immunotools; clone:UCHT4), anti-human CCR7 FITC (Rand D systems; clone:150503) anti-human CD45RA APC (Biolegend; clone:HI-100), anti-human CD28-APC (BD biosciences; clone:CD28.2), anti-human CD57-FITC (eBiosciences; clone:HDC57), anti-human CD69-FITC (eBiosciences; clone:FN50), anti-human CD25-APC (eBiosciences; clone:BC96), anti-human HLADR-FITC (eBiosciences; clone: H1.2 F3), anti-human KLRG1-FITC (Biolegend; clone:2 F1/KLRG1), anti-human CD279-APC (eBiosciences; clone:eBioJ105). Appropriate isotype controls were used for setting gates. Following incubation, cells were washed and resuspended in PBS for flow cytometric analysis using a Cyan $^{\text {tm }}$ ADP flow cytometer (Dako). T cells can be classified into four distinct subsets on the basis of expression of cell surface markers, CCR7 and CD45RA; naïve $\left(\mathrm{CD} 45 \mathrm{RA}^{+\mathrm{ve}} \mathrm{CCR}^{+\mathrm{ve}}\right)$, central memory $\left(\mathrm{CD} 45 \mathrm{RA}^{\text {-ve }}\right.$ $\left.\mathrm{CCR} 7^{\text {+ve }}\right)$, effector memory $\left(\mathrm{CD} 45 \mathrm{RA}^{\text {-ve }} \mathrm{CCR} 7^{-\mathrm{ve}}\right)$ and effector memory RA (CD45RA ${ }^{\text {-ve }}$ CCR7 $^{-v e}$ ) [32]. The gating strategy used to identify $\mathrm{T}$ cell subsets is shown in Figure 1c-f.

\section{In-vitro cultures of PBMCs to induce cytokine production by $T$ cells}

PBMC cultures were performed in complete RPMI 1640 (Sigma Aldrich, UK) containing 10\% FCS (Biosera, UK) supplemented with glutamine/penicillin/streptomycin (Life Technologies, UK). PBMCs were stimulated for $4 \mathrm{hr}$ with PMA (50 ng/ml; Sigma Aldrich, UK) and Ionomycin (500 ng/ml; Sigma Aldrich, UK) in the presence of Brefeldin A (10 $\mu \mathrm{g} / \mathrm{ml}$; Sigma Aldrich, UK). Post-stimulation, cells were washed twice with PBS and 
stained using anti-human CD3 PEcy7 (eBiosciences, UK; clone: UCHT1) and anti-human CD4 Alexa fluor 450 (eBiosciences, UK; clone: RPA-T4) for $20 \mathrm{~min}$ in the dark at $4^{\circ} \mathrm{C}$. Cells were washed and fixed with $50 \mu \mathrm{l}$ Reagent A (Fix and Perm kit, Invitrogen, UK) for 30 minutes in the dark at room temperature. Post incubation, cells were washed and re-suspended in $50 \mu \mathrm{l}$ Reagent B (Fix and Perm kit, Invitrogen, UK) and anti-human TNFa PE (eBiosciences, UK; clone: MAb11) or anti-human IL6 APC (eBiosciences, UK; clone: MQ213A5) or anti-human IL17A Alexa fluor 647 (Biolegend, UK; clone:ebio64Dec13) or anti-human IFNy APC (Bio legend, UK ;clone: AS.B3) and anti-human IL4 PE (eBiosciences, UK; clone:8D4-8) was added and samples were incubated in the dark at room temperature for 30 minutes. After washing the cells were analysed on a Cyan ${ }^{\mathrm{nt}}$ ADP (Dako Ltd, UK).

\section{Serum cytokines and cortisol}

Serum IL- 6 and TNF $\alpha$ were measured using multiplex technology and a commercial 5-plex kit (BioRad, Hemel Hempstead, UK). Serum cortisol was measured using a commercial ELISA kit (IBL international, Hamburg, Germany).

\section{Statistical analysis}

Univariate ANOVA with least significant difference posthoc tests were used to assess differences between the three groups (hip fracture with depressive symptoms, hip fracture without depressive symptoms, and healthy controls). Where demographic variables differed significantly between the three groups, analyses were rerun adjusting for these variables using ANCOVA. Pearson's correlations were used to examine associations between depression score/serum hormone levels/circulating cytokine levels and $\mathrm{T}$ cell phenotype and cytokine production.

\section{Additional file}

Additional file 1: Figure S1. $C D 28^{-v e} \operatorname{CD} 57^{\text {tve }} T$ lymphocytes in hip fracture patients. Percentage of (a) $\mathrm{CD} 28^{- \text {ve }} \mathrm{CD} 57^{\text {tve }} \mathrm{CD} 4 \mathrm{~T}$ cells, or (b) $\mathrm{CD}_{28} 8^{\text {-ve }} \mathrm{CD} 57^{+\mathrm{ve}} \mathrm{CD} 8 \mathrm{~T}$ cells in healthy controls $(n=23)$, hip fracture patients without depressive symptoms $(H F ; n=19)$ and hip fracture patients without depressive symptoms ( $H F+D ; n=17)$. The solid bar represents the mean value. ${ }^{*} p<.05$. Figure S2. Association between circulating pro-inflammatory cytokines and senescent T cells. Correlation between (a) serum IL6 levels and the frequency of circulating CD28-ve CD57 $7^{\text {tve }}$ T cells $(n=44)(b)$ serum TNFa levels and frequency of circulating $\mathrm{CD}^{- \text {-ve }} \mathrm{CD}^{\text {+ve }} \mathrm{T}^{\text {T cells }}(\mathrm{n}=29)$.

\section{Competing interests}

The authors declare that they have no competing interests.

\section{Acknowledgements}

We are grateful to the following hospital consultants for their assistance: Professor Sir Keith

Porter (Queen Elizabeth Hospital Birmingham), Mr Martin Goodman (Queen Elizabeth

Hospital Birmingham), Mr Edward Davis (Russell's Hall Hospital Dudley) and Mr Sanjay

Mistry (Heartlands Hospital Birmingham). We acknowledge the support of the NIHR-Wellcome Trust Clinical Research Facility, Queen Elizabeth Hospital Birmingham. NAD, JU and PH recruited patients and carried out the experimental work; ACP and NAD carried out the statistical analyses; NAD, $\mathrm{ACP}$ and $\mathrm{JML}$ contributed to writing the manuscript and ACP and JML designed the study.

\section{Funding}

This research was supported by funding from the Research Councils UK New Dynamics of Ageing initiative administered through the Economic and Social Research Council (project RES-356-25-0011).

\section{Author details}

${ }^{1}$ School of Immunity and Infection, University of Birmingham, Birmingham B15 2TT, UK. ${ }^{2}$ MRC-Arthritis Research UK Centre for Musculoskeletal Ageing Research and, University of Birmingham, Birmingham B15 2TT, UK. ${ }^{3}$ School of Sport, Exercise and Rehabilitation Sciences, University of Birmingham, Birmingham B15 2TT, UK.

Received: 22 July 2014 Accepted: 6 December 2014

Published online: 16 December 2014

\section{References}

1. Dicarlo AL, Fuldner R, Kaminski J, Hodes R: Aging in the context of immunological architecture, function and disease outcomes. Trends Immunol 2009, 30(7):293-294.

2. Steinmann GG, Klaus B, Muller-Hermelink HK: The involution of the ageing human thymic epithelium is independent of puberty. A Morphometric Study Scand I Immunol 1985, 22(5):563-575.

3. Pawelec G, Larbi A, Derhovanessian E: Senescence of the human immune system. J Comp Pathol 2010, 142(Suppl 1):S39-S44.

4. Utsuyama M, Hirokawa K, Kurashima C, Fukayama M, Inamatsu T, Suzuki K, Hashimoto W, Sato K: Differential age-change in the numbers of CD4 + CD45RA+ and CD4 + CD29+ T cell subsets in human peripheral blood. ech Ageing Dev 1992, 63(1):57-68.

5. De Paoli P, Battistin S, Santini GF: Age-related changes in human lymphocyte subsets: progressive reduction of the CD4 CD45R (suppressor inducer) population. Clin Immunol Immunopathol 1988 48(3):290-296.

6. Ouyang $\mathrm{Q}$, Wagner WM, Voehringer $\mathrm{D}$, Wikby $\mathrm{A}$, Klatt $\mathrm{T}$, Walter $\mathrm{S}$, Müller $\mathrm{CA}$, Pircher H, Pawelec G: Age-associated accumulation of CMV-specific CD8+ T cells expressing the inhibitory killer cell lectin-like receptor G1 (KLRG1). Exp Gerontol 2003, 38(8):911-920.

7. Kudlacek S, Jahandideh-Kazempour S, Graninger W, Willvonseder R, Pietschmann P: Differential expression of various T cell surface markers in young and elderly subjects. Immunobiology 1995, 192(3-4):198-204.

8. Vallejo AN: CD28 extinction in human T cells: altered functions and the program of T-cell senescence. Immunol Rev 2005, 205:158-169.

9. Czesnikiewicz-Guzik M, Lee WW, Cui D, Hiruma Y, Lamar DL, Yang ZZ, Ouslander JG, Weyand CM, Goronzy JJ: T cell subset-specific susceptibility to aging. Clin Immunol 2008, 127(1):107-118.

10. Haynes $L$, Eaton $S M$ : The effect of age on the cognate function of CD4+ T cells. Immunol Rev 2005, 205:220-228.

11. Sandmand M, Bruunsgaard H, Kemp K, Andersen-Ranberg K, Pedersen AN, Skinhøj P, Pedersen BK. Is ageing associated with a shift in the balance between Type 1 and Type 2 cytokines in humans?

12. Sindermann J, Kruse A, Frercks HJ, Schütz RM, Kirchner H: Investigations of the lymphokine system in elderly individuals. Mech Ageing Dev 1993, 70(1-2):149-159.

13. MCNerlan SE, Rea IM, Alexander HD: A whole blood method for measurement of intracellular TNF-alpha, IFN-gamma and IL-2 expression in stimulated CD3+ lymphocytes: differences between young and elderly subjects. Exp Gerontol 2002, 37(2-3):227-234. 
14. Luz C, Dornelles F, Preissler T, Collaziol D, da Cruz IM, Bauer ME: Impact of psychological and endocrine factors on cytokine production of healthy elderly people. Mech Ageing Dev 2003, 124(8-9):887-895.

15. Segerstrom SC, Miller GE: Psychological stress and the human immune system: a meta-analytic study of 30 years of inquiry. Psychol Bull 2004, 130(4):601-630.

16. Hawkley LC, Cacioppo JT: Stress and the aging immune system. Brain Behav Immun 2004, 18(2):114-119.

17. Butcher SK, Killampalli V, Chahal H, Kaya Alpar E, Lord JM: Effect of age on susceptibility to post-traumatic infection in the elderly. Biochem Soc Trans 2003, 31(2):449-451

18. Khanfer R, Lord JM, Phillips AC: Neutrophil function and cortisol:DHEAS ratio in bereaved older adults. Brain Behav Immun 2011, 25(6):1182-1186.

19. Koval KJ, Zuckerman JD: Functional recovery after fracture of the hip. The Journal of bone and joint surgery. J Bone Joint Surg Am 1994, 76(5):751-758.

20. Johnell O, Gullberg B, Allander E, Kanis JA: The apparent incidence of hip fracture in Europe: a study of national register sources. Osteoporos Int 1992, 2(6):298-302.

21. Cole MG, Dendukuri N: Risk factors for depression among elderly community subjects: a systematic review and meta-analysis. Am J Psychiatry 2003, 160(6):1147-1156.

22. Holmes JD, House AO: Psychiatric illness in hip fracture. Age Ageing 2000, 29(6):537-546

23. Nightingale S, Holmes J, Mason J, House A: Psychiatric illness and mortality after hip fracture. Lancet 2001, 357(9264):1264-1265.

24. Mossey JM, Knott K, Craik R: The effects of persistent depressive symptoms on hip fracture recovery. J Gerontol 1990, 45(5):M163-M168.

25. Tsigos C, Chrousos GP: Hypothalamic-pituitary-adrenal axis, neuroendocrine factors and stress. J Psychosomatic Res 2002, 53(4):865-871.

26. Hazeldine J, Arlt W, Lord JM: Dehydroepiandrosterone as a regulator of immune cell function. J Steroid Biochem Mol Biol 2010, 120(2-3):127-136.

27. Aguilera G: HPA axis responsiveness to stress: implications for healthy aging. Exp Gerontol 2011, 46(2-3):90-95.

28. Vermeulen A: Dehydroepiandrosterone sulfate and aging. Ann N Y Acad Sci 1995, 774:121-127.

29. Buford TW, Willoughby DS: Impact of DHEA(S) and cortisol on immune function in aging: a brief review. Appl Physiol Nutr Metab 2008, 33(3):429-433.

30. Butcher SK, Killampalli V, Lascelles D, Wang K, Alpar EK, Lord JM: Raised cortisol:DHEAS ratios in the elderly after injury: potential impact upon neutrophil function and immunity. Aging Cell 2005, 4(6):319-24.

31. Duggal NA, Upton J, Phillips AC, Hampson P, Lord JM: Depressive symptoms are associated with reduced neutrophil function in hip fracture patients. Brain Behav Immun 2013, 33:173-182.

32. Geginat J, Sallusto F, Lanzavecchia A: Cytokine-driven proliferation and differentiation of human naive, central memory, and effector memory CD4(+) T cells. J Exp Med 2001, 194(12):1711-1719.

33. Focosi D, Bestagno M, Burrone O, Petrini M: CD57+ T lymphocytes and functional immune deficiency. J Leukoc Biol 2010, 87(1):107-16.

34. Voehringer $D$, Koschella M, Pircher H: Lack of proliferative capacity of human effector and memory T cells expressing killer cell lectinlike receptor G1 (KLRG1). Blood 2002, 100(10):3698-3702.

35. Kamphorst AO, Ahmed R: Manipulating the PD-1 pathway to improve immunity. Curr Opin Immunol 2013, 25(3):381-388.

36. Wherry EJ: T cell exhaustion. Nat Immuno/ 2011, 12(6):492-499

37. Channappanavar R, Twardy BS, Krishna P, Suvas S: Advancing age leads to predominance of inhibitory receptor expressing CD4 T cells. Mech Ageing Dev 2009, 130(10):709-12.

38. Shimada Y, Hayashi M, Nagasaka Y, Ohno-Iwashita Y, Inomata M: Ageassociated up-regulation of a negative co-stimulatory receptor PD-1 in mouse CD4+ T cells. Exp Gerontol 2009, 44(8):517-522

39. Moussavi S, Chatterji S, Verdes E, Tandon A, Patel V, Ustun B: Depression, chronic diseases, and decrements in health: results from the World Health Surveys. Lancet 2007, 370(9590):851-858.

40. Irwin MR, Miller AH: Depressive disorders and immunity: 20 years of progress and discovery. Brain Behav Immun 2007, 21(4):374-383.

41. Schleifer SJ, Keller SE, Meyerson AT, Raskin MJ, Davis KL, Stein M: Lymphocyte function in major depressive disorder. Arch Gen Psychiatry 1984, 41(5):484-486.

42. Kronfol Z, House JD: Lymphocyte mitogenesis, immunoglobulin and complement levels in depressed patients and normal controls. Acta Psychiatr Scand 1989, 80(2):142-147.
43. Charmandari E, Tsigos C, Chrousos G: Endocrinology of the stress response. Annu Rev Physiol 2005, 67:259-284.

44. Leonard BE, Myint A: The psychoneuroimmunology of depression. Hum Psychopharmacol 2009, 24(3):165-75.

45. Herold MJ, McPherson KG, Reichardt HM: Glucocorticoids in T cell apoptosis and function. Cell Mol Life Sci 2006, 63(1):60-72.

46. Atanackovic D, Kröger $H$, Serke $S$, Deter $H C$ : Immune parameters in patients with anxiety or depression during psychotherapy. Affect Disord 2004, 81(3):201-209.

47. Bașterzi AD, Yazici K, Buturak V, Cimen B, Yazici A, Eskandari G, Tot Acar S, Taşdelen B: Effects of venlafaxine and fluoxetine on lymphocyte subsets in patients with major depressive disorder: a flow cytometric analysis. Prog Neuropsychopharmacol Biol Psychiatry 2010, 34(1):70-75.

48. Maes M, Lambrechts J, Bosmans E, Jacobs J, Suy E, Vandervorst C, de Jonckheere C, Minner B, Raus J: Evidence for a systemic immune activation during depression: results of leukocyte enumeration by flow cytometry in conjunction with monoclonal antibody staining. Psychol Med 1992, 22(1):45-53.

49. Maes M, Stevens W, DeClerck L, Bridts C, Peeters D, Schotte C, Cosyns P: Immune disorders in depression: higher $\mathrm{T}$ helper/T suppressor-cytotoxic cell ratio. Acta Psychiatr Scand 1992, 86(6):423-431.

50. Amati $M$, Tomasetti M, Ciuccarelli M, Mariotti L, Tarquini LM, Bracci M, Baldassari M, Balducci C, Alleva R, Borghi B, Mocchegiani E, Copertaro A, Santarelli L: Relationship of job satisfaction, psychological distress and stress-related biological parameters among healthy nurses: a longitudinal study. J Occup Health 2010, 52(1):31-38.

51. Kern F, Ode-Hakim S, Vogt K, Hoflich C, Reinke P, Volk HD: The enigma of CD57 + CD28- T cell expansion-anergy or activation? Clin Exp Immunol 1996, 104(1):180-184.

52. Trzonkowski P, Myśliwska J, Godlewska B, Szmit E, Łukaszuk K, Wieckiewicz J, Brydak L, Machała M, Landowski J, Myśliwski A: Immune consequences of the spontaneous pro-inflammatory status in depressed elderly patients. Brain Behav Immunity 2004, 18(2):135-48.

53. Effros RB: Telomere/telomerase dynamics within the human immune system: effect of chronic infection and stress. Exp Gerontol 2011 46(2-3):135-140.

54. Saurwein-Teissl M, Lung TL, Marx F, Gschösser C, Asch E, Blasko I, Parson W, Böck G, Schönitzer D, Trannoy E, Grubeck-Loebenstein B: Lack of antibody production following immunization in old age: association with CD8(+) CD28(-) T cell clonal expansions and an imbalance in the production of Th1 and Th2 cytokines. J Immunol 2002, 168(11):5893-5899.

55. Bryl E, Vallejo AN, Weyand CM, Goronzy JJ: Down-regulation of CD28 expression by TNF-alpha. J Immunol 2001, 167(6):3231-3238.

56. Pourgheysari $B$, Khan N, Best D, Bruton R, Nayak L, Moss PA: The cytomegalovirus-specific CD4+ T-cell response expands with age and markedly alters the CD4+ T-cell repertoire. J Virol 2007, 81(14):7759-7765.

57. Morley JK, Batliwalla FM, Hingorani R, Gregersen PK: Oligoclonal CD8+ T cells are preferentially expanded in the CD57+ subset. J Immunol 1995, 154(11):6182-6190.

58. Maes M: Depression is an inflammatory disease, but cell-mediated immune activation is the key component of depression. Prog Neuropsychopharmacol Biol Psychiatry 2011, 35(3):664-675.

59. Duggal NA, Beswetherick A, Upton J, Hampson P, Phillips AC, Lord JM: Depressive symptoms in hip fracture patients are associated with reduced monocyte superoxide production. Exp Gerontol 2014, 54:27-34.

60. Maes M, Stevens WJ, Declerck LS, Bridts CH, Peeters D, Schotte C, Cosyns P: Significantly increased expression of T-cell activation markers (interleukin-2 and HLA-DR) in depression: further evidence for an inflammatory process during that illness. Prog Neuropsychopharmacol Biol Psychiatry 1993, 17(2):241-255.

61. Zorrilla EP, Luborsky L, McKay JR, Rosenthal R, Houldin A, Tax A, McCorkle R, Seligman DA, Schmidt K: The relationship of depression and stressors to immunological assays: a meta-analytic review. Brain Behav Immun 2001, 15(3):199-226

62. Pavón L, Sandoval-López G, Eugenia Hernández M, Loría F, Estrada I, Pérez M, Moreno J, Avila U, Leff P, Antón B, Heinze G: Th2 cytokine response in Major Depressive Disorder patients before treatment. J Neuroimmunol 2006, 172(1-2):156-165.

63. Ouyang $X$, Yang Z, Zhang R, Arnaboldi $P$, Lu G, Li Q, Wang W, Zhang B, Cui M, Zhang H, Liang-Chen J, Qin L, Zheng F, Huang B, Xiong H: Potentiation of Th17 cytokines in aging process contributes to the development of colitis. Cell Immunol 2011, 266(2):208-217. 
64. Chen $Y$, Jiang $T$, Chen P, Ouyang J, Xu G, Zeng Z, Sun Y: Emerging tendency towards autoimmune process in major depressive patients: a novel insight from Th17 cells. Psychiatry Res 2011, 188(2):224-230.

65. Leonard BE: The concept of depression as a dysfunction of the immune system. Curr Immunol Rev 2010, 6(3):205-212.

66. Dowlati Y, Herrmann N, Swardfager W, Liu H, Sham L, Reim EK, Lanctôt KL: A meta-analysis of cytokines in major depression. Biol Psychiatry 2010, 67(5):446-457.

67. Maes M, Scharpé S, Meltzer HY, Bosmans E, Suy E, Calabrese J, Cosyns P: Relationships between interleukin- 6 activity, acute phase proteins, and function of the hypothalamic-pituitary-adrenal axis in severe depression. Psychiatry Res 1993, 49(1):11-27.

68. Lanquillon S, Krieg JC, Bening-Abu-Shach U, Vedder H: Cytokine production and treatment response in major depressive disorder. Neuropsychopharmacology 2000, 22(4):370-379.

69. Phillips AC, Upton J, Duggal NA, Carroll D, Lord JM: Depression following hip fracture is associated with increased physical frailty in older adults: the role of the cortisol: dehydroepiandrosterone sulphate ratio. BMC Geriatrics 2013, 13:60.

70. Yesavage JA, Brink TL, Rose TL, Lum O, Huang V, Adey M, Leirer VO. Development and validation of a geriatric depression screening scale: a preliminary report. J Psychiatr Res. 1982-1983;17(1):37-49.1982. 17(1): p. 37-49.

71. Zigmond AS, Snaith RP: The hospital anxiety and depression scale. Acta Psychiatr Scand 1983, 67(6):361-70.

72. Bjelland I, Dahl AA, Haug TT, Neckelmann D: The validity of the Hospital Anxiety and Depression Scale. J Psychosom Res 2002, 52(2):69-77.

\section{Submit your next manuscript to BioMed Central and take full advantage of:}

- Convenient online submission

- Thorough peer review

- No space constraints or color figure charges

- Immediate publication on acceptance

- Inclusion in PubMed, CAS, Scopus and Google Scholar

- Research which is freely available for redistribution 